\title{
PENGATURAN JANGKA WAKTU KEPEMILIKAN RUMAH TUNGGAL OLEH ORANG ASING DI ATAS TANAH HAK PAKAI ATAS HAK MILIK \\ Oleh
}

\author{
I Dewa Made Nhara Prana Pradnyana \\ Ida Bagus Wyasa Putra \\ I Ketut Wirawan \\ Program Magister Kenotariatan Universitas Udayana \\ email : dewanhara@gmail.com
}

\begin{abstract}
ABSTRAK
Jangka waktu orang asing untuk dapat memiliki rumah tunggal di atas tanah hak pakai atas hak milik berdasarkan Pasal 7 Peraturan Pemerintah Nomor 103 Tahun 2015 bertentangan dengan jangka waktu yang dapat dimiliki orang asing atas tanah hak pakai atas hak milik berdasarkan Pasal 49 Peraturan Pemerintah Nomor 40 Tahun 1996.

Berdasarkan kondisi tersebut, permasalahan yang dirumuskan dalam penelitian ini adalah (1) Bagaimanakah karakteristik masalah pengaturan jangka waktu kepemilikan rumah tunggal oleh orang asing di atas tanah hak pakai atas hak milik; (2) Bagaimanakah formulasi kebijakan pengaturan pemecahan masalah jangka waktu kepemilikan rumah tunggal oleh orang asing di atas tanah hak pakai atas hak milik?

Berangkat dari adanya konflik norma, penelitian ini menggunakan penelitian hukum normatif dengan pendekatan perundang-undangan, konseptual dan historis. Sumber bahan hukum dalam penelitian ini terdiri dari bahan hukum primer, sekunder dan tersier yang dikumpulkan dengan teknik bola salju. Teknik analisis bahan hukum yang digunakan adalah teknik deskripsi, komparasi, evaluasi dan argumentasi.

Hasil penelitian ini menunjukkan bahwa (1) Karakteristik masalah pengaturan jangka waktu kepemilikan rumah tunggal oleh orang asing di atas tanah hak pakai atas hak milik dari diberlakukannya Pasal 7 PP No. 103 Tahun 2015 berdasarkan asas Lex specialis derogat legi generali sehubungan dengan adanya konflik norma antara lain meliputi: ketidaksesuaian antara pengaturan jangka waktu tanah hak pakai atas hak milik oleh orang asing dan Warga Negara Indonesia; dan tidak diakomodirnya bentuk akta sehubungan dengan perpanjangan jangka waktu kepemilikan rumah tunggal oleh orang asing di atas tanah hak pakai atas hak milik; (2) Formulasi kebijakan pengaturan pemecahan masalah berhubungan dengan dilakukannya revisi terhadap pasal-pasal dalam peraturan perundang-undangan yang langsung berkaitan dengan karakteristik permasalahan yang ada sebagai langkah pengharmonisasian norma.
\end{abstract}

Kata Kunci: Jangka Waktu, Rumah Tunggal, Hak Pakai atas Hak Milik, Orang Asing.

\section{ABSTRACT}

The period of time for foreigners to be able to have a single term of house on the land use rights on proprietary under Article 7 of Government Regulation Number 103 year 2015 contradicted to the period of time that can be owned by foreigners on land use rights on proprietary rights under Article 49 of Government Regulation Number 40 year 1996.

Under these conditions, the problem formulated in this study were (1) How do the characteristics of problem related to regulatory of period of time for the single term of house ownership by foreigners on the land use rights on proprietary?; (2) How the policies formulation of troubleshooting regulatory of period of time for the single term of house ownership by foreigners on the land use rights on proprietary?

Departing from the norm conflict, this study uses normative legal research' approach to legislation, conceptual and historical. Sources of law material in this research consists of primary legal materials, secondary and tertiary collected by the 
snowball technique. Legal materials analysis technique used were techniques of description, comparison, evaluation and argumentation.

The results of this study indicate that (1) Characteristics of problem related to regulatory of period of time for the single term of house ownership by foreigners on the land use rights on proprietary under the implementation of Article 7 of Regulation Number 103 year 2015 is based on the principle of Lex specialis derogat legi generali in relation to the conflict of norms include: a mismatch between the provision of land use rights period on top of the property by foreigners and Indonesian citizen; and the unaccommodated deed related to the extension of the term of a single house ownership by on the land use rights on proprietary; (2) Policies formulation of troubleshooting settings related to the revision of provisions in the legislation which is directly related to the characteristics of the existing problems as the norm of harmonization's step.

Keywords: Term, Single house, The land use rights on proprietary, Foreigner.

\section{Pendahuluan}

Seiring meningkatnya jumlah orang asing yang melakukan usaha dan kerja di Indonesia, permintaan kebutuhan rumah tempat tinggal bagi orang asing juga semakin meningkat. Peraturan Pemerintah No. 103 Tahun 2015 tentang tentang Pemilikan Rumah Tempat Tinggal atau Hunian oleh Orang Asing yang Berkedudukan di Indonesia (untuk selanjutnya disebut PP No. 103 Tahun 2015) hadir sebagai suatu kebijakan yang memberikan kepastian hukum bagi orang asing yang ingin memperoleh hak atas tanah untuk rumah tempat tinggal dengan tetap memegang prinsipprinsip pertanahan di Indonesia

Dalam Pasal 7 PP No. 103 Tahun 2015 ditentukan bahwa orang asing dapat memiliki rumah tunggal di atas tanah hak pakai atas hak milik dengan jangka waktu sesuai dengan jangka waktu yang disepakati dan tidak lebih lama dari tiga puluh tahun. Apabila jangka waktu tersebut berakhir, maka Hak Pakai dapat diperpanjang untuk jangka waktu paling lama dua puluh tahun sesuai kesepakatan dengan pemegang hak atas tanah. Lebih lanjut, dalam hal waktu perpanjangan telah berakhir, maka Hak Pakai dapat diperbaharui untuk jangka waktu paling lama tiga puluh tahun sesuai kesepakatan dengan pemegang hak atas tanah.

Ketentuan dalam Pasal 7 PP No. 103 Tahun 2015 tersebut apabila diamati memiliki perbedaan yang cukup signifikan dengan ketentuan dalam Pasal 49 Peraturan Pemerintah No. 40 Tahun 1996 tentang Hak Guna Usaha, Hak Guna Bangunan dan Hak Pakai (untuk selanjutnya disebut PP No. 40 Tahun 1996) yang menentukan bahwa Hak Pakai atas tanah Hak Milik dapat diberikan untuk jangka waktu paling lama dua puluh lima tahun dan tidak dapat diperpanjang. Orang asing yang berkedudukan di Indonesia merupakan salah satu subjek hukum hak pakai yang diatur dalam PP No. 40 Tahun 1996.

Adanya ketentuan mengenai jangka waktu di atas tanah hak pakai atas hak milik yang tidak sinkron antara PP No. 40 Tahun 1996 dan PP No. 103 Tahun 2015 menggambarkan adanya konflik norma yang terjadi di dalam peraturan perundang-undangan yang sederajat, yakni Peraturan Pemerintah.

Berangkat dari adanya konflik norma sebagaimana dipaparkan di atas, maka diperlukan suatu penelitian yang dilakukan secara komprehensif dan mendalam sehubungan 
dengan pengaturan jangka waktu kepemilikan rumah tunggal bagi orang asing di atas tanah hak pakai atas hak milik.

Berdasarkan uraian di atas, adapun permasalahan yang dapat dirumuskan adalah sebagai berikut:

1. Bagaimanakah karakteristik masalah pengaturan jangka waktu kepemilikan rumah tunggal oleh orang asing di atas tanah hak pakai atas hak milik?

2. Bagaimanakah formulasi kebijakan pengaturan pemecahan masalah jangka waktu kepemilikan rumah tunggal oleh orang asing di atas tanah hak pakai atas hak milik?

\section{Metode Penelitian}

Penyusunan tesis ini menggunakan penelitian hukum normatif ${ }^{1}$ yang beranjak dari adanya konflik norma antara Pasal 7 PP No. 103 Tahun 2015 dan Pasal 49 PP No. 40 Tahun 1996. Penelitian ini menggunakan pendekatan perundang-undangan, konseptual dan historis. Sumber bahan hukum dalam penelitian ini terdiri dari bahan hukum primer, bahan hukum sekunder, dan bahan hukum tersier. Teknik pengumpulan bahan hukum dalam penelitian ini menggunakan teknik bola salju. Adapun teknik analisis bahan hukum dalam penelitian ini menggunakan teknik deskripsi, komparasi, evaluasi dan argumentasi.

\section{TEORI DAN TINJAUAN UMUM}

\subsection{Konsep Negara Hukum}

Suatu Negara dapat dikatakan sebagai suatu Negara Hukum dengan memperhatikan prinsipprinsip yang terdapat dalam Negara tersebut. Frederich Julius Stahl memaparkan empat prinsip yang terdapat dalam suatu Negara Hukum yang oleh Negara

${ }^{1}$ Ida Bagus Wyasa Putra, 2016, Teori Hukum Dengan Orientasi Kebijakan, Udayana University Press, Denpasar, h. 57. penganut Civil Law dikenal dengan sebutan Rechtstaat. Adapun prinsip-prinsip tersebut antara lain meliputi:

1. Pengakuan dan perlindungan terhadap hak-hak asasi manusia;

2. Negara didasarkan pada teori trias politica;

3. Pemerintahan diselenggarakan berdasarkan undang-undang (Wetmatiig Bestuur);

4. Adanya peradilan administrasi negara yang bertugas menangani kasus perbuatan melanggar hukum oleh pemerintah (onrechmatige overheidsdaad). ${ }^{2}$

Menurut Sri Soemantri Martosoewigjono, Negara Indonesia merupakan Negara Hukum yang berdasarkan Pancasila dengan unsur-unsur yang dimiliki sebagai berikut:

1. Adanya pengakuan terhadap jaminan hak-hak asasi manusia dan warga negara;

2. Adanya pembagian kekuasaan;

3. Bahwa dalam melaksanakan tugas dan kewajiban, pemerintah harus selalu berdasarkan atas hukum yang berlaku, baik yang tertulis maupun yang tidak tertulis;

4. Adanya kekuasaan kehakiman yang dalam menjalankan kekuasaannya merdeka, artinya terlepas dari pengaruh kekuasaan pemerintah, sedang khusus untuk Mahkamah Agung harus juga merdeka dari pengaruh-pengaruh lainnya. ${ }^{3}$

\subsection{Konsep Hak atas Tanah}

Hak atas tanah atau yang menurut Urip Santoso disebut sebagai hak penguasaan atas tanah, merupakan "hak yang

${ }^{2}$ Titik Triwulan Tutik, 2010, Konstruksi Hukum Tata Negara Indonesia Pasca Amandemen UUD 1945, Kencana, Jakarta, hal. 61.

${ }^{3}$ Astim Riyanto, 2006, Teori Konstitusi, Penerbit Yapendo, Bandung, hal. 277. 
berisi serangkaian wewenang, kewajiban dan/atau larangan bagi pemegang haknya untuk berbuat sesuatu mengenai tanah yang dihaki". ${ }^{4}$

Setiap orang berkesempatan untuk memiliki hak atas tanah di Indonesia, namun dengan memperhatikan Asas Kenasionalan pada Pasal 1 ayat (1), ayat (2) dan ayat (3) Undang-Undang Nomor 5 Tahun 1960 tentang Peraturan Dasar Pokok-Pokok Agraria (untuk selanjutnya disebut UUPA) dan Asas Hanya Warga Negara Indonesia yang Mempunyai Hak Milik Atas Tanah pada Pasal 9 ayat (2) dan Pasal 21 ayat (1) UUPA, maka orang dengan kewarganegaraan selain Indonesia atau orang asing memiliki batasan-batasan atas hak atas tanah yang dapat dimiliki di Indonesia. Adapun hak-hak atas tanah yang dapat dimiliki oleh orang asing hanya terbatas pada hak pakai dan juga hak sewa yang keduanya memiliki batasan jangka waktu yang harus diperhatikan.

\subsection{Konsep Rumah Tunggal}

Rumah tunggal berdasarkan Pasal 1 angka 2 PP No. 103 Tahun 2015 didefinisikan sebagai "rumah yang mempunyai kaveling sendiri dan salah satu dinding bangunan tidak dibangun tepat pada batas kaveling". Orang asing dapat memiliki rumah tunggal di atas tanah hak pakai ataupun di atas tanah hak pakai atas hak milik dengan memperhatikan jangka waktu yang ditentukan dalam PP No. 103 Tahun 2015.

Rumah tunggal yang dapat dimiliki oleh orang asing diberikan dengan batasan harga

${ }^{4}$ Urip Santoso, 2013, Hukum Agraria Kajian Komprehensif, Cetakan Ketiga, Penerbit Kencana Prenada Media Group, Jakarta, hal. 10. minimal sebagaimana tercantum dalam lampiran Peraturan Menteri Agraria dan Tata Ruang/ Kepala Badan Pertanahan Nasional Republik Indonesia Nomor 29 Tahun 2016 tentang Tata Cara Pemberian, Pelepasan atau Pengalihan Hak atas Pemilikan Rumah Tempat Tinggal atau Hunian oleh Orang Asing yang Berkedudukan di Indonesia. Disamping batasan harga minimal tersebut, rumah tunggal yang dapat dimiliki oleh orang asing dibatasi dengan ketentuan satu bidang tanah per orang per keluarga dengan tanah paling luas dua ribu meter persegi. Pemberian rumah tempat tinggal dapat diberikan dengan luas lebih dari dua ribu meter persegi dalam keadaan tertentu yang mempunyai dampak positif luar biasa terhadap ekonomi dengan izin Menteri.

\subsection{Teori Kepastian Hukum}

Gustav Radbruch menyatakan bahwa "sesuatu yang dibuat pasti memiliki cita atau tujuan", begitu pula hukum yang dibuat dengan tujuan tertentu. Adapun tujuan hukum yang utama sesungguhnya ada tiga, yaitu: adanya keadilan untuk keseimbangan, kepastian untuk ketetapan dan kemanfaatan untuk kebahagiaan.

Menurut Peter Mahmud Marzuki, kepastian hukum mengandung dua pengertian, yaitu:

"pertama, adanya aturan yang bersifat umum membuat individu mengetahui perbuatan apa yang boleh atau tidak boleh dilakukan dan kedua, berupa keamanan hukum bagi individu dari kesewenangan pemerintah karena dengan adanya aturan yang bersifat umum itu individu dapat mengetahui apa saja

${ }^{5}$ Muhammad Erwin, 2011, Filsafat Hukum: Refleksi Krisis Terhadap Hukum, PT. Raja Grafindo Persada, Jakarta, hal. 123. 
yang boleh dibebankan atau dilakukan negara terhadap individu."6

\subsection{Teori \\ Peraturan undangan}

Pembentukan

Pembentukan Perundang-

peraturan perundang-undangan pada
hakikatnya ialah pembentukan norma-norma hukum yang berlaku keluar dan bersifat umum dalam arti yang luas. ${ }^{7}$ Teori pembentukan peraturan perundang-undangan yang baik menurut L. Fuller setidaktidaknya harus menghindari delapan hal yang olehnya disebut delapan hal yang fatal, yakni:

a. Failure to establish rules at all, leading to absolute uncertainty.

b. Failure to make rule public to those required to observe them.

c. Improper use of retroactive law making.

d. Failure to make comprehensible rules.

e. Making rules which contradict each other.

f. Making rules which impose requirements with which complience is impossible.

g. Changing rule so frequently........

h. Discontinuity between.... ${ }_{8} \ldots$ content and ... ... practice. $^{8}$

\subsection{Teori Hierarki Norma}

Teori Hierarki Norma atau yang dikenal dengan sebutan Stufenbau Theory merupakan teori yang dikemukakan oleh Hans Kelsen yang menyatakan bahwa sistem hukum merupakan sistem anak tangga dengan kaidah berjenjang.

"The unity of these norms is constituted by the fact that the

${ }^{6}$ Peter Mahmud Marzuki, 2008, Pengantar Ilmu Hukum, Prenada Media, Jakarta, hal. 158.

${ }^{7}$ Yuliandri, 2009, Asas-Asas Pembentukan Peraturan Perundang-Undangan Yang Baik (Gagasan Pembentukan Undang-Undang Berkelanjutan), Rajawali Pers, Jakarta, hal. 25.

${ }^{8}$ H. M. Coubrey \& N. D. White, 1996, Textbook on Jurisprudence, Blackstone Press Limited, London, hal. 89. creation of the norm-the lower oneis determined by another-the higherthe creation of which of determined by a still higher norm, and that this regressus is terminated by a highest, the basic norm which, being the supreme reason of validity of the whole legal order, constitutes its unity." ",

Apabila terjadi konflik misalnya antara dua undangundang, akan berlaku secara konsisten asas-asas preferensi, yaitu: lex specialis derogate legi generalis, lex posterior derogate legi priori, lex superior derogate legi inferiori. ${ }^{10}$

\subsection{Teori Harmonisasi Hukum}

Menurut Wacipto Septiadi, paling tidak terdapat tiga fungsi dari harmonisasi hukum yang antara lain meliputi:

1. Pengharmonisasian dilakukan untuk menjaga keselarasan, kemantapan, dan kebulatan konsepsi peraturan perundangundangan sebagai sistem dengan tujuan peraturan tersebut dapat berfungsi secara efektif,

2. Harmonisasi hukum dilakukan sebagai upaya preventif, dalam rangka pencegahan diajukannya permohonan judicial review peraturan perundang-undangan kepada kekuasaan kehakiman yang berkompeten.

3. Menjamin proses pembentukan peraturan perundang-undangan dilakukan secara taat asas hukum, demi kepentingan dan kepastian hukum. ${ }^{11}$

${ }^{9}$ Hans Kelsen, 2009, General Theory of Law and State, Translated by Anders Wedberg, Harvard University Printing Office Cambridge, Massachusetts, USA, hal. 124.

${ }^{10}$ Zainuddin Ali, 2009, Filsafat Hukum, Sinar Grafika, Jakarta, (selanjutnya disebut Zainuddin Ali I), hal. 118.

${ }^{11}$ Wacipto Septiadi, 2007, Proses Pengharmonisasian sebagai Upaya untuk Memperbaiki Kualitas Peraturan PerundangUndangan, Jurnal Legislatif Indonesia Vol. 4 No. 2 Bulan Juni, hal. 48. 


\subsection{Teori Kewenangan}

Philipus

M.

Hadjon

berpendapat bahwa kewenangan pada hakikatnya berasal dari dua sumber, yakni atribusi dan delegasi. Namun disamping itu, kadangkala mandat digunakan sebagai cara tersendiri dalam memperoleh wewenang. ${ }^{12}$

\subsection{Tinjauan Umum}

\subsubsection{Tinjauan Umum tentang} Hak atas Tanah

Ketentuan hukum hak atas tanah didasarkan pada Pasal 4 ayat (1) UUPA yang menyatakan bahwa:

"Atas dasar hak menguasai dari negara atas tanah sebagaimana yang dimaksud dalam Pasal 2 ditentukan adanya macam-macam hak atas permukaan bumi, yang disebut tanah, yang dapat diberikan kepada dan dipunyai oleh orang-orang, baik sendiri maupun bersama-sama dengan orang-orang lain serta badanbadan hukum."

Hak atas tanah pada dasarnya adalah sebuah kewenangan untuk "memakai" suatu bidang tanah tertentu dalam memenuhi suatu kebutuhan tertentu. ${ }^{13}$ Macammacam hak atas tanah diatur secara jelas di dalam Pasal 16 ayat (1) UUPA yang antara lain meliputi:

a. Hak milik,

b. Hak guna usaha,

c. Hak guna bangunan,

d. Hak pakai,

e. Hak sewa,

f. Hak membuka tanah,

g. Hak memungut hasil hutan,

h. Hak-hak lain yang tidak termasuk dalam hak-hak tersebut di atas

${ }^{12}$ Philipus M. Hadjon, dkk, 1993, Pengantar Hukum Administrasi Negara dan Upaya Administrasi di Indonesia, Liberty, Yogyakarta, hal. 128.

${ }^{13}$ Mohammad Machfudh Zarqoni, 2015, Hak Atas Tanah, Prestasi Pustakaraya, Jakarta, hal. 36. yang akan ditetapkan dengan undang-undang serta hak-hak yang sifatnya sementara sebagai yang disebutkan dalam Pasal 53.

3.9.2 Tinjauan Umum tentang Hak Pakai atas Tanah

Dalam Pasal 41 ayat (1) UUPA, hak pakai didefinisikan sebagai:

"Hak untuk menggunakan dan/atau memungut hasil dari tanah yang dikuasai langsung oleh Negara atau tanah milik orang lain, yang memberi wewenang dan kewajiban yang ditentukan dalam keputusan pemberiannya oleh pejabat yang berwenang memberikannya atau dalam perjanjian dengan pemilik tanahnya, yang bukan perjanjian sewa-menyewa atau perjanjian pengolahan tanah, segala sesuatu asal tidak bertentangan dengan jiwa dan ketentuan undang-undang ini."

Pasal 42 UUPA menetapkan bahwa yang dapat memiliki hak pakai atas tanah antara lain meliputi:

1. Warga Negara Indonesia;

2. Orang asing yang berkedudukan di Indonesia;

3. Badan hukum yang didirikan menurut hukum Indonesia dan berkedudukan di Indonesia;

4. Badan hukum asing yang mempunyai perwakilan di Indonesia.

Asal tanah hak pakai adalah tanah yang langsung dikuasai oleh negara atau tanah milik orang lain. Tanah yang dikuasai langsung oleh negara, diberikan dalam bentuk keputusan pemberian hak oleh pejabat yang berwenang, sedangkan tanah milik orang lain diberikan berdasarkan perjanjian dengan pemilik tanah tersebut.

\subsubsection{Tinjauan Umum tentang Hak Pemilikan Rumah Tempat Tinggal oleh Orang Asing di Indonesia}


Pasal 4 PP No. 103 Tahun 2015 menentukan bahwa rumah tempat tinggal yang dapat dimiliki orang asing merupakan rumah tunggal di atas tanah hak pakai ataupun tanah hak pakai atas hak milik; dan satuan rumah susun yang dibangun di atas bidang tanah hak pakai.

Rumah tunggal berdasarkan Pasal 1 angka 2 PP No. 103 Tahun 2015 diartikan sebagai "rumah yang mempunyai kaveling sendiri dan salah satu dinding bangunan tidak dibangun tepat pada batas kaveling", sedangkan satuan rumah susun (sarusun) dalam Pasal 1 angka 3 PP No. 103 Tahun 2015 diartikan sebagai "unit rumah susun yang tujuan utamanya digunakan secara terpisah dengan fungsi utama sebagai tempat hunian dan mempunyai sarana penghubung ke jalan umum". Setiap rumah tempat tinggal ataupun hunian, baik rumah tunggal maupun sarusun memiliki ketentuan hukum terkait jangka waktu yang harus dipatuhi oleh orang asing.

\subsubsection{Tinjauan Umum tentang Kedudukan Orang Asing di Indonesia}

Dalam Pasal 1 angka 1 PP No. 103 Tahun 2015 ditentukan bahwa "Orang asing yang berkedudukan di Indonesia yang selanjutnya disebut Orang asing adalah orang yang bukan Warga Negara Indonesia yang keberadaannya memberikan manfaat, melakukan usaha, bekerja, atau berinvestasi di Indonesia".

Setiap orang asing di Indonesia dibatasi ruang geraknya. Sehubungan dengan bidang perekonomian, orang asing yang melakukan kerja dan usaha di Indonesia harus memiliki izin kerja dan izin usaha yang sah sebagai usaha pencegahan terhadap adanya pekerjaan ataupun usaha orang asing yang berpotensi membahayakan kepentingan nasional.

Di bidang agraria sehubungan dengan ranah kepemilikan atau penguasaan tanah, UUPA menyatakan bahwa orang asing hanya dimungkinkan untuk memiliki hak pakai atas tanah.

\section{KARAKTERISTIK MASALAH PENGATURAN JANGKA WAKTU KEPEMILIKAN RUMAH TUNGGAL OLEH ORANG ASING DI ATAS TANAH HAK PAKAI ATAS HAK MILIK}

\subsection{Pengaturan Jangka Waktu Kepemilikan Rumah Tunggal oleh Orang Asing di atas Tanah Hak Pakai atas Hak Milik}

Adanya ketentuan hukum mengenai jangka waktu di atas tanah hak pakai atas hak milik yang tidak sinkron antara PP No. 40 Tahun 1996 dan PP No. 103 Tahun 2015 menggambarkan adanya konflik norma secara horizontal. Dalam hal terjadinya konflik norma diantara kedua Peraturan Pemerintah tersebut, maka yang dijadikan pisau analisa adalah asas lex specialis derogat legi generali.

Merujuk pada asas lex specialis derogat legi generali, maka sehubungan dengan jangka waktu kepemilikan rumah tunggal oleh orang asing di atas tanah hak pakai atas hak milik, dasar hukum yang digunakan adalah PP No. 103 Tahun 2015, khususnya Pasal 7, karena dalam hal ini PP No. 103 Tahun 2015 merupakan lex specialis daripada PP No. 40 Tahun 1996.

Dengan berlakunya Pasal 7 PP No. 103 Tahun 2015 berdasarkan asas lex specialis 
derogat legi generali dalam menentukan jangka waktu kepemilikan rumah tunggal oleh orang asing di atas tanah hak pakai atas hak milik, berarti orang asing dapat memiliki rumah tunggal di atas tanah hak pakai atas hak milik dengan jangka waktu paling lama tiga puluh tahun sesuai dengan kesepakatan bersama pemegang hak, untuk kemudian dapat dilakukan perpanjangan dengan jangka waktu paling lama dua puluh tahun sebelum dilakukan pembaharuan.

Di sisi yang lain, diberlakukannya Pasal 7 PP No. 103 Tahun 2015 juga menimbulkan permasalahanpermasalahan baru. Permasalahan-permasalahan tersebut antara lain terkait dengan ketidaksesuaian antara pengaturan jangka waktu tanah hak pakai atas hak milik oleh orang asing dan Warga Negara Indonesia; serta permasalahan terkait dengan akta perpanjangan jangka waktu kepemilikan rumah tunggal oleh orang asing di atas tanah hak pakai atas hak milik.

\subsubsection{Ketidaksesuaian antara} Pengaturan Jangka Waktu Tanah Hak Pakai atas Hak Milik oleh Orang Asing dan Warga Negara Indonesia

PP No. 40 Tahun 1996 menentukan dalam Pasal 39 bahwa yang dapat mempunyai hak pakai bukan hanya orang asing yang berkedudukan di Indonesia, melainkan juga Warga Negara Indonesia. Diberlakukannya Pasal 7 PP No. 103 Tahun 2015 memberi kesan bahwa PP No. 103 Tahun 2015 terlalu memanjakan orang asing dibandingkan dengan Warga Negara Indonesia sebagai sesama subjek hukum hak pakai dengan lebih lamanya orang asing dapat memiliki hak pakai atas hak milik, khususnya terkait dengan kepemilikan rumah tunggal.

Perbedaan pengaturan jangka waktu antara orang asing dan Warga Negara Indonesia tersebut tidak sesuai dengan ketentuan Pasal 33 ayat (3) UUD 1945 sebagai dasar dibentuknya UUPA.

\subsubsection{Akta \\ Jangka \\ Perpanjangan \\ Kepemilikan Waktu Tunggal oleh Orang Asing di atas Tanah Hak Pakai atas Hak Milik}

Hadirnya ketentuan sebagaimana dinyatakan dalam Pasal 7 ayat (2) PP No. 103 Tahun 2015 membawa konsekuensi pada diperlukannya akta sebagai dasar dari adanya suatu kesepakatan terkait dengan perpanjangan tersebut. Dengan merujuk pada ketentuan pada Pasal 4 huruf a angka 2 PP No. 103 Tahun 2015 yang telah dipaparkan sebelumnya, dapat diketahui bahwa sehubungan dengan kepemilikan rumah tunggal di atas tanah hak pakai atas hak milik oleh orang asing yang pemberiannya dilakukan dengan menggunakan akta Pejabat Pembuat Akta Tanah (PPAT), maka sehubungan dengan perpanjangannya tentunya juga akan memerlukan akta PPAT.

Permasalahan timbul manakala bentuk akta PPAT yang diperlukan sehubungan dengan perpanjangan pemilikan rumah tunggal di atas tanah hak pakai atas hak milik ini tidak diatur dalam Peraturan Kepala Badan Pertanahan Nasional Republik Indonesia Nomor 8 Tahun 2012 tentang Perubahan atas Peraturan Menteri Negara Agraria/ Kepala Badan Pertanahan Nasional Nomor 3 Tahun 1997 (Perkaban No. 8 Tahun 2012) yang secara 
jelas mengatur tentang bentukbentuk akta yang dapat dibuat oleh PPAT.

\section{Harmonisasi Pengaturan Jangka Waktu Kepemilikan Rumah Tunggal oleh Orang Asing di atas Tanah Hak Pakai atas Hak Milik}

\subsection{Harmonisasi Norma}

\subsubsection{Harmonisasi Norma Pengaturan Jangka Waktu Kepemilikan Rumah Tunggal oleh Orang Asing di atas Tanah Hak Pakai atas Hak Milik}

Pengharmonisasian norma dalam peraturan perundangundangan yang berbeda dilakukan dengan jalan melakukan perubahan atau revisi dalam suatu peraturan perundang-undangan.

Kesesuaian jangka waktu sesungguhnya dapat saja dilakukan dengan melakukan revisi terhadap salah satu ketentuan hukum di antara kedua PP, baik Pasal 49 PP No. 40 Tahun 1996 ataupun Pasal 7 PP No. 103 Tahun 2015, namun merujuk pada Paket Kebijakan Pemerintah Republik Indonesia guna lebih menggerakan perekonomian nasional akan dirasa lebih tepat apabila revisi dilakukan terhadap Pasal 49 PP No. 40 Tahun 1996 sehubungan dengan jangka waktu hak pakai atas hak milik yang dapat dimiliki subjek-subjek hukum hak pakai atas tanah. Perubahan yang dilakukan dalam Pasal 49 PP No. 40 Tahun 1996 tentu perlu mengacu pada Pasal 7 PP No. 103 Tahun 2015 yang menyatakan bahwa orang asing dapat memiliki rumah tunggal di atas tanah hak pakai atas hak milik dengan jangka waktu paling lama tiga puluh tahun, untuk kemudian dapat diperpanjang dengan jangka waktu paling lama dua puluh tahun sesuai dengan kesepakatan, untuk kemudian apabila perpanjangan tersebut telah berakhir dapat dilakukan pembaharuan.

Direvisinya Pasal 49 PP No. 40 Tahun 1996 untuk kemudian disesuaikan dengan ketentuan hukum dalam Pasal 7 PP No. 103 Tahun 2015 tentunya akan menghilangkan kesan diskriminatif kepada Warga Negara Indonesia dalam kaitannya dengan jangka waktu tanah hak pakai atas hak milik.

\subsubsection{Harmonisasi Norma Akta Perpanjangan Jangka Waktu Kepemilikan Rumah Tunggal oleh Orang Asing di atas Tanah Hak Pakai atas Hak Milik}

Terdapat dua alternatif upaya pemecahan masalah dalam hal ini, yang pertama ialah upaya pemecahan masalah dengan dibuatnya suatu pengaturan khusus tentang bentuk akta PPAT yang dibutuhkan dalam hal dilakukannya perpanjangan jangka waktu kepemilikan rumah tunggal oleh orang asing di atas tanah hak pakai atas hak milik guna mengharmonisasikan ketentuan hukum dalam PP No. 103 Tahun 2015 dan Perkaban No. 8 Tahun 2012, dan upaya pemecahan masalah yang kedua, yakni upaya pemecahan masalah yang bersifat sementara dalam artian upaya ini dapat dilakukan sebelum pengaturan khusus tentang bentuk akta PPAT bersangkutan ditetapkan.

Dengan tidak berwenangnya PPAT sebagai pejabat yang membuat akta terkait perpanjangan jangka waktu kepemilikan rumah tunggal orang asing di atas tanah hak pakai atas hak milik, maka akta notaris dapat digunakan sebagai dasar 
dilakukannya perpanjangan jangka waktu kepemilikan rumah tunggal oleh orang asing di atas tanah hak pakai atas hak milik dengan mengacu pada Pasal 15 ayat (2) Undang-Undang No. 2 Tahun 2014 tentang Perubahan atas Undang-Undang Nomor 30 Tahun 2004 tentang Jabatan Notaris (UUJN-P).

Pengharmonisasian norma dengan jalan melakukan revisi terkait peraturan yang mengatur bentuk akta PPAT, yakni Permen Agraria No. 3 Tahun 1997 dan juga Perkaban No. 8 Tahun 2012 sebagai perubahan atas Permen Agraria No. 3 Tahun 1997 akan memberikan kepastian hukum sehubungan dengan dilakukannya perpanjangan jangka waktu kepemilikan rumah tunggal oleh orang asing di atas tanah hak pakai atas hak milik.

\subsection{Formulasi Norma}

\subsubsection{Formulasi}

Norma

Pengaturan Jangka Waktu Kepemilikan Rumah Tunggal oleh Orang Asing di atas Tanah Hak Pakai atas Hak Milik

Formulasi kebijakan atau norma dalam dilakukannya perubahan pada suatu peraturan perundang-undangan merupakan tahap atau proses yang penting karena implementasi dan evaluasi terkait kebijakan atau norma tersebut akan dapat berlangsung dengan baik apabila formulasi bersangkutan telah dirumuskan dengan baik.

Perubahan

peraturan perundang-undangan mungkin saja dilakukan pada PP No. 103 Tahun 2015, namun hal tersebut tidak akan sesuai dengan landasan filosofis daripada ditetapkannya PP No. 40 Tahun 1996 dan PP No. 103 Tahun 2015 itu sendiri dalam kaitannya dengan pelaksanaan pembangunan nasional serta mendukung pembangunan yang semakin meningkat seiring kerjasama Indonesia dengan negara-negara sahabat. Hal ini disebabkan karena jangka waktu yang lebih lama dan dapat diperpanjang pada PP No. 103 Tahun 2015 bertujuan untuk meningkatan investasi di sektor properti yang akan berimplikasi pada meningkatnya pembangunan nasional, mengingat mutlaknya arti penting pembangunan ekonomi bagi negara-negara berkembang ${ }^{14}$ dan disamping itu, diterbitkannya PP No. 103 Tahun 2015 merupakan akibat dari diluncurkannya Paket Kebijakan Tahap I September 2015 oleh Pemerintah Republik Indonesia guna menggerakan perekonomian nasional yang secara tidak langsung pelaksanaannya akan lebih dibutuhkan dan diprioritaskan.

Mengacu pada alasan di atas, maka akan dirasa lebih tepat apabila Pasal 49 PP No. 40 Tahun 1996 diubah dan disesuaikan dengan jangka waktu sebagaimana ditentukan pada Pasal 7 PP No. 103 Tahun 2015 menjadi:

(1) Hak pakai atas tanah hak milik diberikan untuk jangka waktu paling lama tiga puluh tahun dan dapat diperpanjang untuk jangka waktu paling lama 20 (dua puluh) tahun sesuai kesepakatan dengan pemegang hak atas tanah.

(2) Dalam hal jangka waktu perpanjangan sebagaimana dimaksud pada ayat (1) berakhir, hak pakai dapat diperbaharui untuk jangka waktu paling lama 30 (tiga puluh) tahun sesuai

\footnotetext{
${ }^{14}$ Ida Bagus Wyasa Putra, 2008, Aspek-Aspek Hukum Perdata Internasional dalam Transaksi Bisnis Internasional, Cetakan Kedua, PT Refika Aditama, Denpasar, hal. 101.
} 
kesepakatan dengan pemegang hak atas tanah.

(3) Perpanjangan dan pembaharuan sebagaimana dimaksud pada ayat (1) dan (2) wajib dicatat dalam buku tanah dan sertifikat hak atas tanah yang bersangkutan.

\subsubsection{Formulasi Norma Akta Perpanjangan Jangka Waktu Kepemilikan Rumah Tunggal oleh Orang Asing di atas Tanah Hak Pakai atas Hak Milik}

Tidak diaturnya bentuk akta yang dalam hal ini adalah akta PPAT guna mendukung dilakukannya perpanjangan jangka waktu kepemilikan rumah tunggal oleh orang asing di atas tanah hak pakai atas hak milik menimbulkan urgensi bahwa ketentuan hukum terkait dengan bentuk akta tersebut harus segera ditetapkan dalam menjamin kepastian hukum pihak-pihak terkait.

Formulasi pengaturan norma dalam mendukung dilakukannya perubahan ataupun revisi terkait peraturan yang mengatur bentuk akta perpanjangan yang dimaksud akan mengacu pada Permen Agraria No. 3 Tahun 1997 dan juga Perkaban No. 8 Tahun 2012 sebagai perubahan atas Permen Agraria No. 3 Tahun 1997 yang mana kedua peraturan tersebut di dalamnya mengatur mengenai bentuk-bentuk akta yang dapat dipergunakan PPAT dalam pembuatan akta.

Dengan merujuk pada Pasal 95 Permen Agraria No. 3 Tahun 1997 dapat diketahui bahwa sesungguhnya pasal yang mengatur tentang akta tanah yang dibuat oleh PPAT sesungguhnya telah ada secara jelas, hanya saja isi dalam Pasal tersebut yang belum dapat mengakomodir dilakukannya perpanjangan jangka waktu kepemilikan rumah tunggal oleh orang asing di atas tanah hak pakai atas hak milik.

Untuk mendukung dapat terlaksananya perpanjangan jangka waktu yang dimaksud, maka diperlukan tambahan bentuk akta yang dapat dibuat oleh PPAT sebagai dasar perubahan data pendaftaran tanah berupa Akta Perpanjangan Pemberian Hak Pakai atas Tanah Hak Milik, sehingga pada perubahannya Pasal 95 tersebut akan menjadi:

(1) Akta tanah yang dibuat oleh PPAT untuk dijadikan dasar pendaftaran perubahan data pendaftaran tanah adalah:

a. Akta Jual Beli;

b. Akta Tukar Menukar;

c. Akta Hibah;

d. Akta Pemasukan ke dalam Perusahaan;

e. Akta Pembagian Hak Bersama;

f. Akta Pemberian Hak Tanggungan;

g. Akta Pemberian Hak Guna Bangunan atas Tanah Hak Milik;

h. Akta Pemberian Hak Pakai atas Tanah Hak Milik;

i. Akta Perpanjangan Pemberian Hak Pakai atas Tanah Hak Milik.

(2) Selain akta-akta sebagaimana dimaksud pada ayat (1) PPAT juga membuat Surat Kuasa Membebankan Hak Tanggungan yang merupakan akta pemberian kuasa yang dipergunakan dalam pembuatan Akta Pemberian Hak Tanggungan.

Dengan diubahnya Pasal 95 Permen Agraria No. 3 Tahun 1997, maka ketentuan-ketentuan hukum yang berhubungan langsung dengan Pasal tersebut juga perlu diubah. Perubahan tersebut dilakukan antara lain pada Pasal 96 Perkaban No. 8 Tahun 2012 berikut lampiran peraturan pada Perkaban No. 8 Tahun 2012. 


\section{Kesimpulan dan Saran}

\subsection{Kesimpulan}

Berdasarkan pembahasan pada bab-bab yang telah diuraikan sebelumnya, maka dapat ditarik kesimpulan, bahwa:

1. Karakteristik masalah pengaturan jangka waktu kepemilikan rumah tunggal oleh orang asing di atas tanah hak pakai atas hak milik dari diberlakukannya Pasal 7 PP No. 103 Tahun 2015 berdasarkan asas Lex specialis derogat legi generali sehubungan dengan adanya konflik norma antara Pasal 7 PP No. 103 Tahun 2015 dengan Pasal 49 PP No. 40 Tahun 1996 antara lain meliputi:

a. ketidaksesuaian antara pengaturan jangka waktu tanah hak pakai atas hak milik oleh orang asing dan Warga Negara Indonesia; dan

b. tidak diakomodirnya bentuk akta sehubungan dengan perpanjangan jangka waktu kepemilikan rumah tunggal oleh orang asing di atas tanah hak pakai atas hak milik dalam Permen Agraria No. 3 Tahun 1997 jo. Perkaban No. 8 Tahun 2012.

2. Formulasi kebijakan pengaturan pemecahan masalah jangka waktu kepemilikan rumah tunggal bagi orang asing di atas tanah hak pakai atas hak milik antara lain meliputi:

a.Dilakukannya

pengharmonisasian berupa revisi terhadap Pasal $49 \mathrm{PP}$

No. 40 Tahun 1996 untuk

kemudian pasal tersebut diselaraskan dengan ketentuan hukum jangka waktu kepemilikan rumah tunggal oleh orang asing di atas tanah hak pakai atas hak milik pada Pasal 7 PP No. 103 Tahun 2015 guna meningkatkan nilai investasi dan mendukung pembangunan nasional.

b.Dilakukannya

pengharmonisasian norma dengan merevisi ketentuan hukum dalam Pasal 95
Permen Agraria No. 3 Tahun 1997 jo. Pasal 96 Perkaban No. 8 Tahun 2012 untuk kemudian dirumuskan bentuk akta PPAT baru berupa akta perpanjangan pemberian hak pakai atas tanah hak milik yang dibutuhkan dalam proses perpanjangan jangka waktu kepemilikan rumah tunggal oleh orang asing di atas tanah hak pakai atas hak milik, namun sebagai alternatif pemecahan masalah yang bersifat sementara, akta notaris dapat digunakan sebagai dasar dilakukannya perpanjangan jangka waktu kepemilikan rumah tunggal oleh orang asing di atas tanah hak pakai atas hak milik berdasarkan Pasal 15 ayat (2) huruf f UUJN-P.

\subsection{Saran}

Adapun saran yang dapat diberikan kepada Pembentuk Peraturan Perundang-Undangan Pemerintah Republik Indonesia berkaitan dengan pengaturan jangka waktu kepemilikan rumah tunggal oleh orang asing di atas tanah hak pakai atas hak milik antara lain agar:

1. Dilakukan revisi sehubungan dengan:

a. pengaturan jangka waktu tanah hak pakai atas hak milik dalam PP No. 40 Tahun 1996 mengingat jangka waktu tanah dengan hak pakai atas hak milik yang dimiliki Warga Negara Indonesia lebih singkat dibandingkan dengan jangka waktu yang dapat dimiliki orang asing atas rumah tunggal setelah diberlakukannya PP No. 103 Tahun 2015.

b. pengaturan bentuk akta PPAT dalam Permen Agraria No. 3 Tahun 1997 jo. Perkaban No. 8 Tahun 2012, sehingga dengan begitu perpanjangan jangka waktu 
sebagai kelanjutan atas pemilikan rumah tunggal oleh orang asing di atas tanah hak pakai atas hak milik yang perjanjiannya didasarkan dengan akta PPAT dapat menciptakan kepastian hukum.

2. Disusun peraturan pelaksanaan yang lebih konkrit dan memberikan jaminan kepastian hukum, khususnya terkait dengan tata cara perpanjangan jangka waktu kepemilikan rumah tunggal oleh orang asing di atas tanah hak pakai atas hak milik, mengingat dapat diperpanjangnya jangka waktu kepemilikan rumah tunggal oleh orang asing di atas tanah hak pakai atas hak milik merupakan suatu hal yang baru.

\section{DAFTAR PUSTAKA}

\section{Buku}

Ali, Zainuddin, 2009, Filsafat Hukum, Sinar Grafika, Jakarta.

Coubrey, H. M. \& N. D. White, 1996, Textbook on Jurisprudence, Blackstone Press Limited, London.

Erwin, Muhammad, 2011, Filsafat Hukum: Refleksi Krisis Terhadap Hukum, PT. Raja Grafindo Persada, Jakarta.

Hadjon, Philipus M., dkk, 1993, Pengantar Hukum Administrasi Negara dan Upaya Administrasi di Indonesia, Liberty, Yogyakarta.

Kelsen, Hans, 2009, General Theory of Law and State, Translated by Anders Wedberg, Harvard University Printing Office Cambridge, Massachusetts, USA.

Marzuki, Peter Mahmud, 2008, Pengantar Ilmu Hukum, Prenada Media, Jakarta.

Riyanto, Astim, 2006, Teori Konstitusi, Penerbit Yapendo, Bandung.

Santoso, Urip, 2013, Hukum Agraria Kajian Komprehensif, Cetakan Ketiga, Penerbit Kencana Prenada Media Group, Jakarta.

Septiadi, Wacipto, 2007, Proses Pengharmonisasian sebagai Upaya untuk Memperbaiki Kualitas Peraturan Perundang-Undangan, Jurnal Legislatif Indonesia Vol. 4 No. 2 Bulan Juni.

Triwulan, Tutik, 2010, Konstruksi Hukum Tata Negara Indonesia Pasca Amandemen UUD 1945, Kencana, Jakarta.

Wyasa Putra, Ida Bagus, 2008, Aspek-Aspek Hukum Perdata Internasional dalam Transaksi Bisnis Internasional, Cetakan Kedua, PT Refika Aditama, Denpasar. , 2016, Teori Hukum Dengan Orientasi Kebijakan, Udayana University Press, Denpasar.

Yuliandri, 2009, Asas-Asas Pembentukan Peraturan PerundangUndangan Yang Baik (Gagasan Pembentukan Undang-Undang Berkelanjutan), Rajawali Pers, Jakarta.

Zarqoni, Mohammad Machfudh, 2015, Hak Atas Tanah, Prestasi Pustakaraya, Jakarta.

\section{Peraturan Perundang-Undangan}

Undang-Undang Republik Indonesia Nomor 5 Tahun 1960 tentang Peraturan Dasar Pokok-Pokok Agraria (Lembaran Negara Republik Indonesia Tahun 1960 Nomor 104, Tambahan Lembaran Negara Republik Indonesia Nomor 2043).

Undang-Undang Republik Indonesia Nomor 2 Tahun 2014 tentang Perubahan atas Undang-Undang Nomor 30 Tahun 2004 tentang 
Jabatan Notaris (Lembaran Negara Republik Indonesia Tahun 2014 Nomor 3, Tambahan Lembaran Negara Nomor 5491).

Peraturan Pemerintah Republik Indonesia Nomor 40 Tahun 1996 tentang

Hak Guna Usaha, Hak Guna Bangunan dan Hak Pakai (Lembaran

Negara Republik Indonesia Tahun 1996 Nomor 58, Tambahan

Lembaran Negara Republik Indonesia Tahun 1996 Nomor 3643).

Peraturan Pemerintah Republik Indonesia Nomor 103 Tahun 2015 tentang

Pemilikan Rumah Tempat Tinggal atau Hunian oleh Orang Asing yang Berkedudukan di Indonesia (Lembaran Negara Republik Indonesia Tahun 2015 Nomor 325, Tambahan Lembaran Negara Republik Indonesia Nomor 5793).

Peraturan Menteri Negara Agraria/ Kepala Badan Pertanahan Nasional

Nomor 3 Tahun 1997 tentang Ketentuan Pelaksanaan Peraturan

Pemerintah Nomor 24 Tahun 1997 tentang Pendaftaran Tanah.

Peraturan Kepala Badan Pertanahan Nomor 8 Tahun 2012 tentang

Perubahan atas Peraturan Menteri Negara Agraria/ Kepala Badan

Pertanahan Nasional Nomor 3 Tahun 1997 tentang Ketentuan

Pelaksanaan Peraturan Pemerintah Nomor 24 Tahun 1997 tentang Pendaftaran Tanah.

Peraturan Menteri Agraria dan Tata Ruang/ Kepala Badan Pertanahan Nasional Republik Indonesia Nomor 29 Tahun 2016 tentang Tata Cara Pemberian, Pelepasan atau Pengalihan Hak atas Pemilikan Rumah Tempat Tinggal atau Hunian oleh Orang Asing yang Berkedudukan di Indonesia.. 